\title{
ENGLISH LANGUAGE TEACHING IN PESANTREN IN INDONESIA: DEVELOPMENT AND CHALLENGES
}

\author{
Umar $^{1}$ \\ STIT Buntet Pesantren Cirebon \\ aangumar80@gmail.com; \\ umar@stit-buntetpesantren.ac.id
}

Umar. (2022). English Language Teaching in Pesantren in Indonesia: Development And Challenges. Journal of English Language and literature. Journal of English Language and literature, 7(1),55-64. doi: 10.37110/jell.v7i1.143

Received: 01-12-2021

Accepted: 02-02-2022

Published:03-03-2022

Abstract: Pesantren is a traditional Islamic educational institution that studies religious knowledge (tafaqquh fi al-dîn) with an emphasis on moral formation of students so that they can practice it with the guidance of kiai and make the kitab kuning book as the primary source and the mosque as the center of activity. The growth of Pesantren as a traditional Islamic boarding school in the urban area has demonstrated that there have been changes in the pesantren itself. However, its existence has not been influenced by sociopolitical, economical, or cultural changes, it does not mean Pesantren does not face problems and challenges externally or internally. This article will talk about some issues such as the development of Pesantren: historical point of view, Pondok Pesantren today and of course the challenges which are occurring around.

Keywords: English Language Teaching, Pesantren, Santri, Islamic Scholar, Development, Challenges

\section{INTRODUCTION}

English Language Teaching or people usually call it as ELT for short, refers to the activity and industry of teaching English to non-native speakers. Based on collinsdictionary.com , ELT is the practice and theory of learning and teaching English for the benefit of people whose first language is not English.

The dominant use of English in every field covering politic, economic and social culture these days has manifested in its gaining a special position in many countries where it is not spoken. In Indonesia, it is a foreign language officially constituted as part of national education curriculum and becomes a requirement in a number of higher education and work force entry. Interestingly,
Pesantren that maintains a vital role among Indonesians has included English alongside other secular sciences and technology as part of its curriculum in its current advancement.

Non-English speaking nations have widely opened their door to allow English to be used in almost every aspect of their life. The number of English user increased very significantly that in 2005 the estimation of the user was between 840 million to 1.34 billion. The number was the sum of both the number of users who speak English as first language and those who speak English as second language. Interestingly, users of English as second language outnumbered the users of English as first language, which English as L1 is $25-40 \%$ and English as L2 is 60-75\% (Yusny 2013:82) 
Indonesia is a part of the South-East Asia countries. The country participates as a member of a regional organization called the Association of South-East Asian Nations (ASEAN) that established in 1967. Besides Indonesia, the members of this organization are Brunei, Cambodia, Laos, Malaysia, Myanmar, The Philippines, Singapore, Thailand, and Vietnam. These countries communicate with each other using English.

Meanwhile, Sutrisno quotes Azyumardi Azra's opinion, a boarding school commonly known as Pesantren or also with education traditional, even though there are already many pesantren modern, is the oldest Islamic educational institution in Indonesia (Arifin 2012:40). In general, the definition of pesantren is a traditional Islamic educational institution that studies religious knowledge (tafaqquh fi al-dîn) with an emphasis on moral formation of students so that they can practice it with the guidance of kiai and make the holy yellow book as the primary source and the mosque as the center of activity.

Pesantren is also interesting to discuss because of some of these arguments. First, Pesantren grow and develop in Islamic society. Second, Pesantren in Indonesia have come a long way. Not long after Islam entered the Archipelago, the embryo of the forerunner of the emergence of Pesantren began to grow. Third, Indonesia is not only a country with the largest Muslim population, but also has the most Pesantren in the world. Fourth, many scientists and national figures have studied at pesantren, such as Idham Khalid, A. Mukti Ali, Nurcholish Madjid, Abdurrahman Wahid (former 4th President of the Republic of Indonesia), Hasyim Muzadi (former chairman of PBNU), Din Syamsuddin (chairman of PP Muhammadiyah), and Hidayat Nur Wahid (former chairman of the MPR).

Pesantren is also known by the addition of the term Pondok which in the sense of the Indonesian word means room, hut, and small house by emphasizing the simplicity of the building. Pondok also comes from the Arabic "Fundũq" which means a bedroom, a guesthouse, a simple hotel, or means a residence made of bamboo. So that the term Islamic boarding school can be interpreted as a place or complex for students to study or recite religious knowledge to kiai or Koran teachers, usually the complex is in the form of a dormitory or small rooms with the building as it is that shows its simplicity.

The growth of Pesantren as a traditional Islamic boarding school in the urban area has demonstrated that there have been changes in the pesantren itself. Some examples of Pesantren existing till now in urban areas are Pesantren for students Buntet Pesantren, Cirebon, Pesantren for Students Hamalatuddzikro, Cirebon and Pesantren AlShighor, Gedongan, Ender, Cirebon. Those three pesantren, at least there are two changes emerging in Pesantren tradition. First, from educational system perspective, not only teaching classical Islamic intellectualism, Pesantren have been also teaching modern sciences to their students which called Santri. Second, from leadership perspective which Pesantren have their unique leader called Kyai, Pesantren recently produce the concept of Kyai as a specific typology for Islamic leaders who are chosen not because of their relation with the former Kyai nor descendants of Kyai, but because of their piousness, spirituality, managerial knowledge and charisma.

It is an undeniable fact that Pesantren is experiencing rapid development. Quantitatively, the number of Pesantren has continued to increase in the last ten years. Based on research conducted by the Research and Development Research and Development Center of the Ministry of Religion, it was found that from 14,656 in 2003-2004 the number of Islamic boarding schools became 28,961 in 2014-2015. The development of Islamic boarding schools qualitatively can be seen from various aspects, including institutional status, administrative arrangements, implementation of educational programs, expansion of the field of work, the peculiarities of the scientific field, diversification of economic business, cooperation 
networks, and others. The diversity of developments produces various expressions of Pesantren in the life of the nation and state.

In organizing educational programs, Pesantren now not only require their students to learn religious knowledge (tafaqquh fi al-dîn) but also encourage their students to study general knowledge such as English. As evidence, many Pesantren are now carrying out Language Days in each Pesantren, not only in Arabic but also in English.

During English Language Teaching (ELT) activities in Pesantren, many stakeholders are involved in order to create conducive situation which is measured and set up to reach maximum output of the educational process. Among these stakeholders, teacher and students are the main actors to determine, although another stakeholder may be also taking part and become influential. Teacher and students have their own perspectives toward the running process of learning, environment and instruments. Students must have personal motivation which determines their perspective as well as learning behavior.

English has been taught in Indonesia since the era of Dutch colonial period. However, the access to education for the locals was very rare. The Dutch policy in establishing education in Indonesia is exclusively for themselves and some of the important local officials. English was first taught to Indonesians in 1914 when junior high schools were established (Yusny 2013:89).

\section{METHOD}

This study adopts library research (Library Research) which contains an in-depth collection of material on one or several subjects (Sawarjuwono and Kadir 2003). This study covers the inclusion of primary sources as well as secondary sources. In the United States, digital library research is guided, and even defined, through the projects supported by Digital Library Initiatives (DLI). The DLI are funded by a consortium of government agencies under the leadership of the National Science Foundation.
Library Research is a type of qualitative research which is generally carried out by not going into the field in search of data sources. Literature research can also be interpreted as research that is carried out only based on written works, including research results both already and unpublished. It is called library research because the data or materials needed to complete the research come from the library in the form of books, encyclopedias, dictionaries, journals, documents, magazines and so on.

Broadly speaking, the reading sources used in this study can be divided into two groups, namely:

1. General sources of reference which usually contain general theories and concepts, namely literature in the form of textbooks, encyclopedias, monographs, and the like.

2. Specific reference sources include journals, research bulletins, theses and others

\section{FINDINGS AND DISCUSSIONS}

Development

1. Historical Point of View

One way of spreading and teaching Islam in Indonesia is carried out by educational institutions known as Pesantren. His role was very large in the early days of the spread of Islam in the archipelago. Even though their role is so big, it is still not clear when Pesantren started to exist in Indonesia. Several sources say different things about when exactly pesantren began to exist in Indonesia.

Pesantren are Indonesian indigenous educational institutions and have taken root in the midst of Indonesian society. Pesantren is one of the wombs that incubates fighters who, apart from being militant, are also fully responsible for their duties and environment. Responsible vertically and horizontally in giving birth and raise Indonesia (Muhakamurrohman 2014:110).

The existence of Pesantren as the oldest Islamic educational institution in Indonesia is 
very helpful in producing cadres of scholars who are reliable in the religious sciences. To realize this goal, the organization of book recitation, in which basic Islamic values are collected which are used as values in forming individuals who are intellectual, have noble character, then a number of books that are determined to be studied in Islamic boarding schools are seen as the curriculum.

According to the late $\mathrm{KH}$. Abdurrahman Wahid (Gus Dur) Islamic boarding school from various angles. Islamic boarding schools as "cultural institutions" that use Javanese cultural symbols; as a "renewal agent" who introduced the idea of rural development (rural development); as a center for learning activities community (center of community learning); and also Islamic boarding schools as Islamic educational institutions that rely on syllabus, brought by Imam Al-Suyuti more than 500 years ago, in Itman al-dirayah (Mustofa 2011:77)

In Pesantren, the santri or students live with their kiai or teacher in a certain complex so as to create the characteristics of Pesantren life such as a close relationship between the kiai and santri, santri obey the kiai, Santri is independent and has simple life, Santri has the spirit of mutual cooperation in a friendly atmosphere. Santri has full of brotherhood, and they have disciplined life.

The noble values that become the basic character of the Pesantren are also evident from the zuhud attitude and modesty of the Pesantren. In the midst of the frenetic hangar of life outside the Pesantren which all prioritizes material, Pesantren still persists with simplicity and modesty, so that from this humble attitude of life the Pesantren remains critical in responding to existing developments, including the current of modernization, and now the flow of globalization, even though Pesantren sometimes considered closed off and resistant to these developments. This is nothing but because departing from the point of view of life, worship gets the highest priority.

The santri from the Pesantren who actually studied during the quarantine period generally would have a militant, religious character as well as being responsible for their obligations. The Pesantren referred to here are, of course, salaf Pesantren with Ahl al-Sunnah Wa alJama'ah orientation, not Islamic boarding schools that are experts in Sunnah only, let alone radical Islamic boarding schools that can be found easily nowadays. In the Pesantren tradition, apart from being taught to recite and study religious knowledge, the students are also taught to practice and be responsible for what they have learned. Pesantren also teach the values of simplicity, independence, the spirit of cooperation, solidarity, and sincerity. From the spirit of sincerity, it makes the alumni of the Pesantren as individuals who are emotionally intelligent, virtuous, and responsible for every mandate they carry. Pesantren continues to grow both in terms of quantity, material, and system. In 1910 several Pesantren, such as Pesantren Denanyar, Jombang, opened a special boarding school for female students.

Departing from the perspective of life as a means of worship, Islamic boarding schools have their own perspective on science. For a santri, seeking knowledge is worship, so many years spent in the Pesantren is never felt as a loss. Because seeking knowledge is worship, religious sciences in Pesantren are included in the category of sacred areas and have their own position in the view of Pesantren. Not just anyone can teach a science without a diploma from a teacher who is believed to have had a strong background on the previous teachers whose teaching background was to the Prophet. Therefore, in 
the Pesantren world that maintains this tradition, the lineage of teachers and oral transmission is still a separate consideration.

From the point of view of life as worship, it can also be understood how the love for religious sciences is firmly entrenched in Pesantren. With this foundation then the religious sciences have their own supremacy which is absolutely enforced in Pesantren, including the system and oral transmission. Thus the perfect way of worship is to seek knowledge continuously and spread it to others without any strings attached.

Kitab, is a special term used to describe written works in the field of religion written in Arabic letters. This designation distinguishes it from other forms of writing in general that use writing other than Arabic and is called a book. The book that is used as a source of learning in Pesantren the Kitab Kuning. In the Pesantren tradition, the Kitab Kuning is a characteristic and identity that cannot be separated. As an institution for the study and development of Islamic sciences, Pesantren make the Kitab Kuning an inherent identity with Pesantren. Even Bruinessen stated that the presence of pesantren should be able to transmit traditional Islam as contained in the yellow books (Van Bruinessen 1995).

The Kitab Kuning can be synonymous with the classic book, but it is more popularly known as the yellow book (Daulay n.d.:71). In the Encyclopedia of Islamic Law it is explained that The Kitab Kuning is a book that contains Islamic sciences, especially jurisprudence, which is written or printed in Arabic letters in Arabic, Malay, and Javanese and so on without using harakat (lines) so it is also called the "book of bare" or "Kitab Gundul" (Dahlan 1996:950).

Since the beginning of the founding of the Pesantren, the tradition of reading, studying classical books has become important, even something that is inherent in the Pesantren. The existence of this yellow book became the main study because at that time Pesantren only studied Islamic sciences, and classical books became the right and accurate choice to be able to explore knowledge about Islam.

In further developments, along with the number of students who have completed their education in Islamic boarding schools, this educational institution is also experiencing rapid development. Because every santri who has graduated from a Pesantren, after returning generally also establishes a Pesantren. This may have something to do with the Islamic boarding school's scientific tradition, which places more emphasis on the process of transferring knowledge and values. The establishment of a new Pesantren by Pesantren alumni can be understood as that process. Thus, Islamic boarding schools were spread in various regions, both in Java and outside Java.

Pesantren must be able to survive so that it becomes a moral stronghold for the nation's generation. Because many parties want moral damage generation of the nation and especially the Muslim generation. They don't just attack physically, more than that, namely through the colonization of thought and culture by destroying the morals of generations of Muslims. In the midst of the war The cross, Peter Venerabilis, makes the statement: (But I attack you not, as some of us [Christians] often do, by arms, but by words; not by force, but by reason; not in hatred, but in love (Mustofa 2011:79).

The pesantren community, especially the Kiai as the highest leader in the pesantren, has a significant role in the development of science, especially religion and culture in the archipelago. Not only that, the pesantren community also colors the pattern and education system in Indonesia to present. 
Historical facts prove that the pesantren community has implemented an education and teaching system in society. The names of scholars from pesantren such as Sheikh KH. Ahmad Khotib Sambas, Sheikh KH. Nawawi al-Bantani, Sheikh KH. Ihsan Jampes, Sheikh KH. Ahmad Kholil Bangkalan, Sheikh K.H. Mahfuz Termas, Sheikh K.H. Abdul Karim, Hadhrotusy Sheikh KH. Hasyim Asy'ari, KH. Wachid Hasyim, KH. Abdurrahman Wahid and so on, are no strangers to the world of education and the development of religious knowledge in Indonesia.

According to Anis Masykur in the Modernization of Islamic Boarding Schools, he wrote that there are five elements that characterize Islamic boarding schools. These five elements are the main requirements for defining a pesantren. (1) Kyai as the leader of the Islamic boarding school, (2) students who live in dormitories and study with the kiyai (3) dormitory as a place for students to live (4) Recitation as a form of teaching the kyai to students, and (5) mosque as a center for education and training Pesantren activities (Yunus 2019:114). However, there are also those who are not uniform in mentioning the elements that characterize the Islamic Boarding School. In 1975, the idea emerged to develop a new Islamic boarding school. The Pondok Karya Pembangunan, Pondok Modern, Islamic Center, and Pondok Pesantren Development were born. However, this Islamic boarding school has difficulties in coaching because there is no charismatic kiai who can provide guidance and role models for his students.

Then many Pesantren have established public schools with public school curricula set by the government. In fact, the Joint Decree of the Minister of Religion, Minister of Home Affairs, Minister of Education and Culture No. 03 of 1975, stipulates that general subjects are at least 70 percent of the entire madrasa curriculum. There are also many madrasas that have established universities such as the AS-Syafi'iyah boarding school and the at-Tahiriyah boarding school. Now, along with the times, Pesantren have become more modern, both in terms of curriculum and physical building. Even so, the simplicity and sincerity depicted by the life of the Kiai and his students. It is still the main value that should be imitated from the teachings of life in Pesantren.

\section{Pondok Pesantren Today}

The response of Pesantren to schools and madrasas founded by Islamic reformists is "to refuse while following the example". Pesantren on the one hand reject the assumptions of the reformists and view them as a serious threat to the Pesantren, but also to some extent follow and imitate the steps of the reformists in order to survive. The Santri reflect the citizens of Pancasila, because they believe in the one and only God, who are faithful and pious, and obediently carry out religious teachings. It is considered that the world of Pesantren is already on its way.

The response of Pesantren in dealing with the development of the school education system, they reject the assumptions and religious understanding of the reformists, but to a certain extent, follow the steps of the modernists in order to survive. Therefore, Islamic boarding schools carry out several adjustments that they consider to support the continuity of the Pesantren, and are also beneficial for the development of their education, such as a grading system, a clearer curriculum and a classical system.

The above adjustment steps are currently being carried out by almost all Pesantren, by opening various educational institutions that adopt a modern education system, which is accompanied by various developments in 
various aspects of their education. Based on the Joint Decree of the Minister of Religion, Minister of Home Affairs, Minister of Education and Culture No. 03 of 1975, many Pesantren have established public schools with public school curricula set by the government. Mastering foreign languages is a mandatory matter for Santri in some Pesantren now. Not only so that Santri can understand every Islamic literature, but so that Santri can have more competitiveness after graduating from Pesantren.

Pesantren today are much more developed than before. In the past, Pesantren only studied religion. Now there are general sciences that can be learned in Pesantren. Thus, the insight of the students is wider and more open. Now it looks like a lot of Pesantren graduates who have become doctors, engineers, in the field of aviation, have penetrated into all fields of science. If what has existed so far is that people become doctors but do not know religion, people who become engineers do not know religion. Now it seems that they are doctors but also know religion, some are engineers but also understand religion, some are pilots who know religion.

The existence of Pesantren in responding to the changes of times, of course, has a commitment to continue presenting a pattern of education that is able to produce qualified human resources development (HRD). To achieve this goal, the students must be equipped with a number of Islamic values combined with skills. At least three things that must be worked on by the boarding school in accordance with the identity of the Pesantren (Siregar 2018:23):

a. The demands of modernization and development of science and technology require scholars to have more abilities, adequate intellectual capacity, insight, access to sufficient knowledge and information and be responsive to developments and changes.

b. Pesantren are still considered weak in the mastery of science and methodology. Pesantren only teach religious knowledge in the sense of transfer of knowledge. So, Pesantren must clearly have potential as a "land" for the development of religious knowledge.

c. The world of Pesantren must be able to position itself as a transformation, motivator, and innovator.

The view that Pesantren only educates about religious knowledge without educating general knowledge is starting to change. Pesantren now realize the necessity of teaching both knowledge. The modern Pesantren has started to consolidate both knowledge. Not only religious knowledge, but also academic subjects such as math, English, economics are taught now in Pesntren.

The view that Pesantren are well developed only in suburb areas and the santri are from small villages has already changed significantly. Pesantren today do not only develop outside of city but also are swift developed within town areas. Parents who live in town started realizing the benefits of the Pesantren system in shaping their children characteristics as well as academics achievement.

The view that graduate of Pesantren will only become an Ustadz or religious teacher, do not possess life skills is incorrect. Graduate from pesantren nowadays can pursue education at a higher level in various fields such as medicine, economics, engineering, agriculture and many others. Because Pesantren graduates are equipped with general as well as religious knowledge. Besides, it is 
also hoped that graduates of Pesantren will be able to create new job vacancies to assist with the communities around them.

Currently, Pesantren has formal schools in its system namely Madrasah or even Vocational High School, productive economical institutions, health clinics (Zakaria 2010:48). Meanwhile, in the area of management, Pesantren has used more modern system management compared to the traditional one. Pesantren can survive and adapt to the changes as well as the people needs. The development of learning for English is also continuously encouraged. Learning Development is a complex multidimensional process and does not only aim to improve perceived deficiencies, but is primarily an attempt to re-examine aspects of the learning system. The learning system is oriented to the formulation of new goals and is always oriented to the needs and changes of society.

Pesantren has now implemented a pesantren curriculum that is integrated with the National Education curriculum, so that the two curricula have integrated achievement targets and competency standards at every level. The development of English Language Teaching (ELT) is based on the thought of the caretaker of the Pesantren. English is believed to be a language that must be mastered, considering that English is an international language and is used by most of the nations in the world. Mastery of English and being able to communicate in English is considered important by developing ELT in Pesantren, so that students can convey Islamic messages to all levels of world society.

Some Pesantren even set up special institutions as important facilities for students who want to develop their English skills. Many Pesantren have changed and view English as a very important subject to be mastered. Besides being able to transfer the message of Islam to people all over the world, English can be a bridge for Santri to be sensitive to the development of knowledge around the world. To be able to master English and be able to communicate with it, it is considered important to develop English Language Teaching in which students can convey Islamic messages to all levels of the world community.

\section{Challenges}

The challenges of modernity in Pesantren can be understood from the education management system. The management of Pesantren is always closely related to planning, organizing, Actuating and Controlling. How the Pesantren plans, organizes, acts, and controls the activities in the Pesantren institutions. Both the activities carried out by santri, Ustadz and institutional activities, as well as how the system recruits Ustadz at the Pesantren. Development of the Pesantren curriculum, Pesantren is an Islamic educational institution with its own characteristics. These characteristics are a reflection of the ideology adopted by the Kiai and then implemented in the teaching and learning process.

The world of education after the presence of the disruptive innovation phenomenon is predicted to enter the era of digitalization of the education system. Teaching and learning activities will change completely. Classrooms have evolved with digital learning patterns that provide learning experiences that are more creative, participatory, diverse, and comprehensive. Presence of technology information has erased geographic boundaries that have led to the emergence of new ways to generate new innovations. Developments in digital technology with Artificial Intelligence (AI) that transforms data into information, making it easy and inexpensive for people to obtain it (Gazali 2018:102).

In the socio-religious context, the challenges of Islamic boarding schools in the RI 4.0 era, in 
addition to facing the struggle of major ideologies and the sophistication of information and communication technology, are also globalization flows that cause various kinds of changes in patterns from all aspects of life. The trend of increasing internet use among millennial youth has implications for changes in consumption patterns of this generation of religious information. Pesantrens can no longer insist on using old methods such as lectures as the only dominant technique in English Language Teaching and learning materials, not only because of the limited reach of their audience segment in space and time but also in terms of flexibility in access to materials. English Language Teaching is absolutely necessary.

This condition needs to be a concern for Pesantren in balancing Islamic literature that is spread through social media, especially messages containing intolerant, liberal and radical conservative ideological biases by producing Islamic literature that is moderate, humanist and tolerant with the aid of technology (Gazali 2018:104).

\section{CONCLUSION}

Pesantren is not only one of the religious education institutions that become the womb of prospective Muslim scholars, but also it has a mandate to carry out an educational mission based on Article 1 (1) of Law Number 20/2003, namely developing the selfpotential of students to have religious spiritual strength, self-control, personality, intelligence, noble character and skills needed by himself, society, nation and state.

1. Pesantren today are much more developed than before. In the past, Pesantren only studied religion. Now there are general sciences that can be learned in Pesantren. Thus, the insight of the students is wider and more open. Now it looks like a lot of Pesantren graduates who have become doctors, engineers, in the field of aviation, have penetrated into all fields of science.

2. In organizing educational programs,
Pesantren now not only require their students to learn religious knowledge (tafaqquh fi aldîn) but also encourage their students to study general knowledge such as English. As evidence, many Pesantren are now carrying out Language Days in each Pesantren, not only in Arabic but also in English.

3. The development of English Language Teaching (ELT) is based on the thought of the caretaker of the Pesantren. English is believed to be a language that must be mastered, considering that English is an international language and is used by most of the nations in the world. Mastery of English and being able to communicate in English is considered important by developing ELT in Pesantren, so that students can convey Islamic messages to all levels of world society.

4. Pesantrens can no longer insist on using old methods such as lectures as the only dominant technique in English Language Teaching and learning materials, not only because of the limited reach of their audience segment in space and time but also in terms of flexibility in access to materials. English Language Teaching is absolutely necessary

\section{REFERENCES}

Arifin, Z. 2012. "Perkembangan Pesantren Di Indonesia." Jurnal Pendidikan Agama Islam 9(1):40-53.

Dahlan, A. A. 1996. "Ensiklopedi Hukum Islam." Jakarta: Ichtiar Baru Van Hoeve.

Daulay, H. P. n.d. Sejarah Pertumbuhan Dan Pembaruan Pendidikan Islam Di Indonesia, Jakarta, Kencana. 2009. Hal.

Gazali, E. 2018. "Pesantren di antara Generasi Alfa dan Tantangan Dunia Pendidikan Era Revolusi Industri 4.0." 2(2):17.

Muhakamurrohman, A. 2014. "Pesantren: Santri, Kiai, dan Tradisi." Ibda' : Jurnal Kajian Islam 
dan Budaya 12(2):109-18. doi: 10.24090/ibda.v12i2.440.

Mustofa, I. 2011. "Menjadikan Pesantren Sebagai Pusat Peradaban Muslim di Indonesia." Millah: Jurnal Studi Agama 11(1):75-108. doi: 10.20885/millah.vol11.iss1.art4.

Sawarjuwono, T and Kadir, A.P. 2003. "Intellectual Capital: Perlakuan, Pengukuran dan Pelaporan (Sebuah Library Research)." Jurnal Akuntansi Dan Keuangan 5(1):35-57. doi: 10.9744/jak.5.1.pp.

Siregar, M. K. 2018. "Pondok Pesantren Antara Misi Melahirkan Ulama Dan Tarikan Modernisasi." Jurnal Pendidikan Agama Islam Al-Thariqah 3(2):16-27. doi: 10.25299/althariqah.2018.vol3(2).2263.

Solichin, M. M. 2013. "Inovasi Pembelajaran di Pesantren: Pengembangan Pembelajaran Bahasa Inggris." NuansA: Jurnal Penelitian Ilmu Sosial dan Keagamaan Islam 10(1). doi: 10.19105/nuansa.v10i1.168.

Van Bruinessen, M. 1995. Kitab Kuning Pesantren dan Tarekat: Tradisi-Tradisi Islam Di Indonesia. Mizan.

Yunus, M. 2019. "Pesantren Sebagai Lembaga Pendidikan Islam Asli Indonesia." Edification Journal : Pendidikan Agama Islam 1(1):111-18. doi: 10.37092/ej.v1i1.87.

Yusny, R. 2013. "ELT in Indonesian Context: Issues and Challenges." Englisia: Journal of Language, Education, and Humanities 1(1):8199. doi: 10.22373/ej.v1i1.140.

Zakaria, G. A. N. 2010. "Pondok Pesantren: Changes and Its Future." 8. 